Note

\title{
A SIMPLE METHOD FOR DNA ISOLATION FROM Xanthomonas spp.
}

\author{
Luiz Humberto Gomes ${ }^{1 *}$; Keila Maria Roncato Duarte ${ }^{1,2}$; Felipe Gabriel Andrino ${ }^{1,2}$; Flavio Cesar \\ Almeida Tavares ${ }^{1}$ \\ ${ }^{1}$ Depto. de Genética - USP/ESALQ, C.P. 83 - CEP: 13418-900 - Piracicaba, SP. \\ ${ }^{2}$ Fellow FAPESP. \\ *Corresponding author <luhgomes@carpa.ciagri.usp.br>
}

\begin{abstract}
A simple DNA isolation method was developed with routine chemicals that yields high quality and integrity preparations when compared to some of the most well known protocols. The method described does not require the use of lysing enzymes, water bath and the DNA was obtained within 40 minutes The amount of nucleic acid extracted (measured in terms of absorbancy at $260 \mathrm{~nm}$ ) from strains of Xanthomonas spp., Pseudomonas spp. and Erwinia spp. was two to five times higher than that of the most commonly used method. Key words: DNA, Xanthomonas, RAPD
\end{abstract}

\section{MÉTODO SIMPLIFICADO DE ISOLAMENTO DE DNA DE Xanthomonas spp.}

\begin{abstract}
RESUMO: Foi desenvolvido um método simplificado de isolamento de DNA utilizando substâncias de uso rotineiro facilitando a metodologia e obtendo-se DNA de alta qualidade e integridade quando comparado com os métodos tradicionais. O método descrito não utiliza enzimas líticas, nem banho-maria, e o DNA é obtido em 40 minutos. As quantificações dos DNAs extraídos (medido em D.O. a $260 \mathrm{~nm}$ ) das dez linhagens de Xanthomonas spp., uma de Pseudomonas spp. e outra de Erwinia spp. mostraram-se de duas a cinco vezes maiores que os métodos conhecidos e suas integridades, testadas em RAPD, apresentaram-se satisfatórias. Palavras-chave: DNA, Xanthomonas, RAPD
\end{abstract}

\section{INTRODUCTION}

Several procedures are described for Xanthomonas DNA isolation (Alvarez et al., 1996; Hartung \& Civerolo, 1987), as well as for Pseudomonas spp. and Erwinia spp., where the bacteria are grown in Wilbrink's agar plates for $72 \mathrm{~h}$ and, cells are treated with egg white lysozyme for $30 \mathrm{~min}$ on ice. The lysis solution (0.5\% SDS, $50 \mathrm{mmol} \mathrm{L}^{-1}$ Tris- $\mathrm{HCl}$, pH 7.5, $400 \mathrm{mmol} \mathrm{L}^{-1}$ EDTA, $1 \mathrm{mg}$ pronase) is added to cell suspension and incubated at $50^{\circ} \mathrm{C}$ in water bath for $3-5 \mathrm{~h}$ and then deproteination is carried out.

Pan et al. (1997) used a simpler method where bacterial cells are grown in $1.5 \mathrm{ml}$ of XAS broth, centrifuged for $8 \mathrm{~min}$ at $1,500 \times \mathrm{g}$, washed in $0.5 \mathrm{ml}$ of STE buffer $\left(100 \mathrm{mmol} \mathrm{L}^{-1} \mathrm{NaCl}, 10 \mathrm{mmol} \mathrm{L}^{-1}\right.$ tris, $\mathrm{pH} 8.0,1 \mathrm{mmol} \mathrm{L}^{-1}$ EDTA) and lysed in $400 \mu \mathrm{l}$ of lysing buffer $(20 \mu \mathrm{l}$ of 1 mol L-1 Tris, pH 8.0, $40 \mu \mathrm{l}$ of $0.5 \mathrm{~mol} \mathrm{~L}^{-1}$ EDTA, $120 \mu \mathrm{l}$ of $10 \%$ SDS, $4 \mu \mathrm{l}$ of 2-mercaptoethanol and $216 \mu \mathrm{l}$ of $\mathrm{H}_{2} \mathrm{O}$. The lysate mix is incubated at $65^{\circ} \mathrm{C}$ for $2 \mathrm{~h}$ and deproteinated. The method described by Ausubel et al. (1992) has been widely used (Lopes et al., 1998; Louws et al.,1994) and cells after and centrifuged for 2 min at $13,000 \times g$, the pellet is resuspended in $567 \mu \mathrm{l}$ of TE buffer, $30 \mu \mathrm{l}$ of $10 \%$ SDS and $3 \mu \mathrm{l}$ of proteinase $\mathrm{K}\left(20 \mathrm{mg} \mathrm{mL}^{-1}\right)$ and incubated at $37^{\circ} \mathrm{C}$ for $1.5 \mathrm{~h}$. Then $100 \mathrm{ul}$ of $5 \mathrm{~mol} \mathrm{~L}^{-1}$
$\mathrm{NaCl}$ and $80 \mu \mathrm{l}$ of CTAB buffer $(10 \mathrm{~g} \mathrm{CTAB}, 4.1 \mathrm{~g} \mathrm{NaCl}$ in $100 \mathrm{ml}$ of water) are added, incubated $10 \mathrm{~min}$. in a $65^{\circ} \mathrm{C}$ water bath. Deproteination is done and isopropanol is used to precipitated the DNA. Other similar methods are cited by Boucher et al. (1985) in the work of Restrepo \& Verdier (1997) and other procedures (Cupples \& Morris, 1990; Kuflu \& Cupples, 1997).

All the protocols cited are able to give large amounts of high quality DNA.

\section{MATERIAL AND METHODS}

The strains used came from the Tropical Culture Collection (CCT - Fundação Tropical de Pesquisas e Tecnologia "André Tosello"- Campinas, SP) (Xanthomonas campestris pv. manihotis; $X$. campestris pv. vesicatoria; $X$. campestris pv. campestris; $X$. maltophilia) and from our laboratories (Erwinia spp., Pseudomonas spp.; $X$. albilineans and $X$. axonopodis pv. phaseoli).

The cultures were grown in $5 \mathrm{ml}$ nutrient broth (Difco) with $10 \%$ glycerol v/v (suggested by Maringoni et al. (1988) to avoid xanthan formation) for $72 \mathrm{~h}$ at $27^{\circ} \mathrm{C}$. One tube of $1.5 \mathrm{ml}$ was used to centrifuged the cells at 13,000 $\mathrm{x} \mathrm{g}$ for $5 \mathrm{~min}$ and the pellet was suspended in $200 \mu \mathrm{l}$ Tris $0.1 \mathrm{~mol} \mathrm{~L}^{-1}$ and added with $200 \mu$ l of lysis solution $(\mathrm{NaOH}$ $0.2 \mathrm{~N}$ and $1 \%$ SDS), mixed and deproteinazed with $700 \mu \mathrm{l}$ of 
phenol/chloroform/isoamyl alcohol (25:24:1 v/v/v), homogenized and centrifuged $10 \mathrm{~min}$ at $13,000 \times \mathrm{g}$.To precipitate DNA, $700 \mu \mathrm{l}$ of cold $95 \%$ ethanol was added and spinned, washed in $70 \%$ ethanol and centrifuged. Precipitated DNA is dried at room temperature and suspended in $100 \mathrm{ul}$ of water. The method described by Ausubel et al. (1992) was performed comparing twelve strains. The samples from the both methods were electrophoresed on $0.8 \%$ agarose gels, stained with ethidium bromide and photographed under UV light. The RAPD was performed according to Williams et al. (1990) using primer OPL 11 (Operon Technologies, USA).

\section{RESULTS AND DISCUSSION}

DNA samples were quantified in spectrophotometer at $260 / 280 \mathrm{~nm}$ and the results can be seen in TABLE 1. The integrity of the samples are shown in Figure 1 and 2, and the quality can be observed in the RAPD shown on Figure 3 and 4, for both methods where in Figure 3 a higher number of polymorphic bands are shown than in Figure 4, using the same primer.

This work presents a simpler high performance and short time consuming procedure for Xanthomonas DNA isolation and for the two other bacteria, Pseudomonas spp. and Erwinia spp.. Samples 260/280 nm ratio was approximately 1.7 to 2.0 in both methods but the quantity and quality seen in agarose gel electrophoresis is higher in the first method.

TABLE 1 - Absorbancy (260 nm) for DNA from Xanthomonas species and from one Pseudomonas spp. and one Erwinia spp. isolated by both methods (Method 1 - method of this paper; Method 2 - method described by Ausubel (1992)) .

\begin{tabular}{|c|c|c|}
\hline & Method 1 & Method 2 \\
\hline Strains & $A_{260 m}$ & $A_{260 \mathrm{~m}}$ \\
\hline & \multicolumn{2}{|c|}{------- ng ul ${ }^{-1}$--.----. } \\
\hline X. campestris pv. citri & 1771 & 330 \\
\hline Erwinia spp. & 1418 & 444 \\
\hline Pseudomonas spp. & 1754 & 361 \\
\hline X. albiline ans & 1672 & 807 \\
\hline $\begin{array}{l}\text { X. albilineans } \\
\text { (Copersucar) }\end{array}$ & 1531 & 326 \\
\hline $\begin{array}{l}\text { X. axo nopodis pv. } \\
\text { phaseoli }\end{array}$ & 1737 & 462 \\
\hline $\begin{array}{l}\text { X. campestris pv. } \\
\text { manihotis - CCT } 0088\end{array}$ & 1572 & 244 \\
\hline $\begin{array}{l}\text { X. campestris pv. } \\
\text { vesicatoria - CCT } 0085\end{array}$ & 924 & 250 \\
\hline $\begin{array}{l}\text { X. campestris pv. } \\
\text { vesicatoria - CCT } 0086\end{array}$ & 1145 & 377 \\
\hline $\begin{array}{l}\text { X. campestris pv. } \\
\text { campestris-CCT } 0369\end{array}$ & 628 & 516 \\
\hline $\begin{array}{l}\text { X. campestris pv. } \\
\text { manihotis - CCT } 1224\end{array}$ & 660 & 324 \\
\hline X. maltophilia - CCT 1897 & 602 & 392 \\
\hline
\end{tabular}

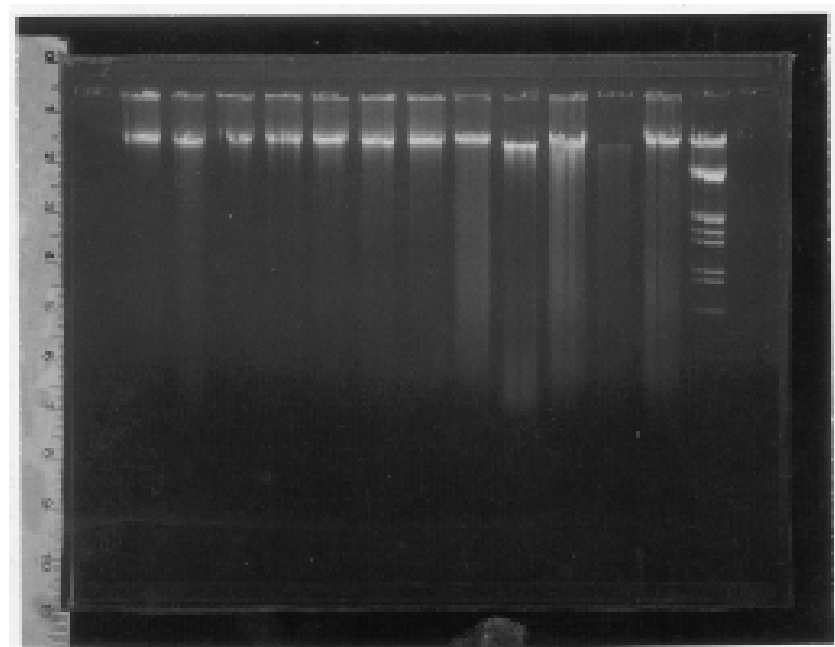

Figure 1 - Xanthomonas DNA isolated by the method proposed. From right to left, $\lambda$ EcoRI-Hind III, $X$. campestris pv. citri, Pseudomonas spp., Erwinia spp., $X$. albilineans, $X$. albilineans (Copersucar), $X$. axonopodis pv. phaseoli, $X$. campestris $p v$. manihotis (CCT 0088), $X$. campestris $p v$. vesicatoria (CCT 0085), $X$. campestris $p v$ vesicatoria (CCT0086), X.campestris pv. campestris (CCT0369), X. campestris pv. manihotis (CCT1224) and X. maltophilia (CCT1897).

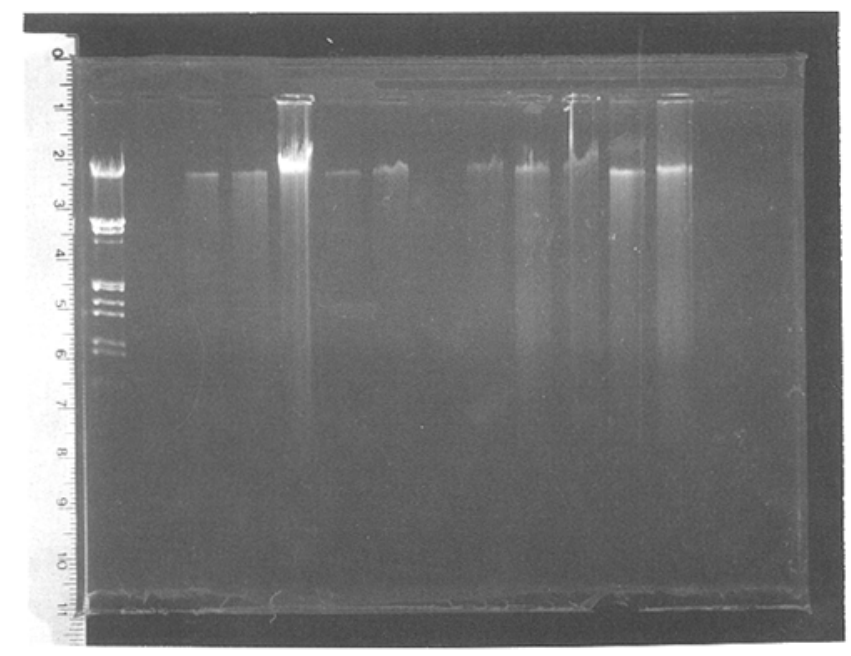

Figure 2 - Xanthomonas DNA isolated by the method on Ausubel (1992). From left to rigth, $\lambda$ EcoRI-Hind III, $X$. campestris pv. citri, Pseudomonas spp., Erwinia spp., $X$. albilineans, $X$. albilineans (Copersucar), $X$. axonopodis pv. phaseoli, $X$. campestris $p v$. manihotis (CCT 0088), $X$. campestris pv. vesicatoria (CCT 0085), X. campestris pv. vesicatoria (CCT0086), $X$. campestris $p v$. campestris (CCT0369), $X$. campestris pv. manihotis (CCT1224) and $X$. maltophilia (CCT1897).

All mentioned methods employ chemicals such as egg white lysosyme, pronase, proteinase $\mathrm{K}$ and require periods of water bath incubation. In addition, the method using pronase (Alvarez et al., 1996; Hartung \& Civerolo, 1987) takes from 4 to 6 hours, the method described by Pan et al. (1997) is simpler but requires water bath and takes about three hours to DNA isolation the DNA. The last described protocol (Ausubel et al., 1992; 


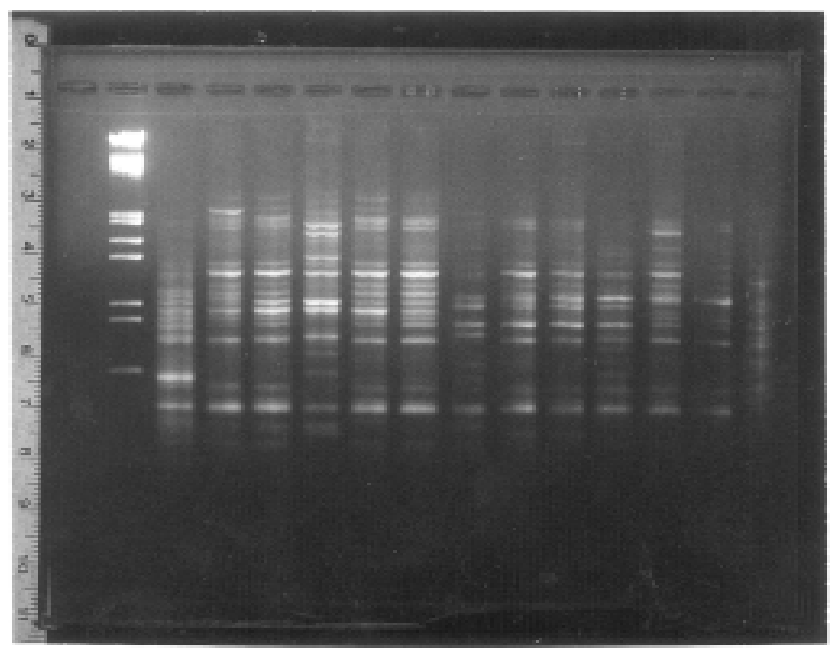

Figure 3 - RAPD from Xanthomonas DNA isolated by the method proposed. From left to right, $\lambda$ EcoRI-Hind III, $X$. campestris pv. citri, Pseudomonas spp., Erwinia spp., $X$. albilineans, $X$. albilineans (Copersucar), $X$. axonopodis pv. phaseoli, $X$. campestris pv. manihotis (CCT 0088), $X$. campestris $p v$. vesicatoria (CCT 0085), $X$. campestris $p v$. vesicatoria (ССТ0086), $X$. campestris pv. campestris (CCT0369), X. campestris pv. manihotis (CCT1224) and X. maltophilia (CCT1897).

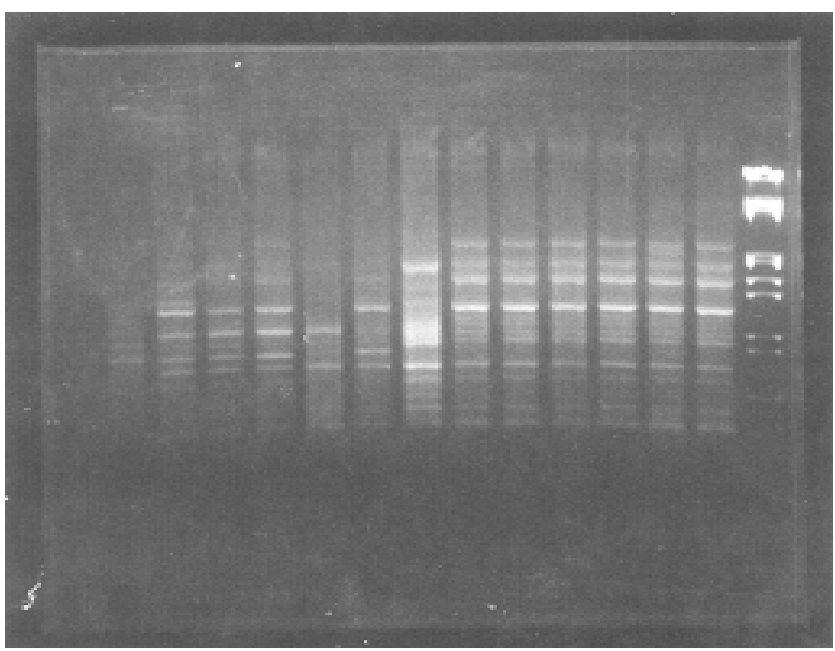

Figure 4 - RAPD from Xanthomonas DNA isolated by the method from Ausubel (1992). From right to left, $\lambda$ EcoRI-Hind III, $X$. campestris pv. citri, Pseudomonas spp., Erwinia spp., $X$. albilineans, $X$. albilineans (Copersucar), $X$. axonopodis pv. phaseoli, $X$. campestris pv. manihotis (CCT 0088), $X$. campestris pv. vesicatoria (CCT 0085), X. campestris pv. vesicatoria (ССТ0086), $X$. campestris $p v$. campestris (CCT0369), X. campestris pv. manihotis (CCT1224) and X. maltophilia (CCT1897).

Lopes et al., 1998; Louws et al., 1994) which was used in comparison to our method requires proteinase $\mathrm{K}$, water bath and three hours for DNA isolation. The presented method has no need of lysis reagents other than $\mathrm{NaOH}$ and SDS and takes about 30 to 40 minutes to total DNA isolation showing that simple reagents can provide good results in DNA isolation, quality and quantity-wise for Xanthomonas species.

\section{ACKNOWLEDGEMENTS}

To Vera Maria Quecini for revising the text and FAPESP for the financial support of this work.

\section{REFERENCES}

ALVAREZ, A.M.; SCHENCK, S.; BENEDICT, A.A. Differentiation of Xanthomonas albilineans strains with monoclonal antibody reaction patterns and DNA fingerprints. Plant Pathology, v.45, p.358-366, 1996.

AUSUBEL, F.M.; BRENT, R.; KINGSTON, R.E.; MOORE, D.D.; SEIDMAN, J.G.; SMITH, J.A.; STRUHL, K. Current protocols in molecular biology. New York: Greene Publishing Association; Wiley-Interscience, 1992. v.1.

BOUCHER, C.; BARBERIS, P.; TRIGALET, A.; DEMERY, D. Transposon mutagenesis of Pseudomonas solanacearum: isolation of Tn-5-induced avirulent mutants. Journal of General Microbiology, v.131, p.2449-2457, 1985.

CUPPLES, D.A.; MORRIS, V.L. Construction and use of a nonradioactive DNA hybridization probe for detection of Pseudomonas syringae pv. tomato on tomato plants. Applied and Environmental Microbiology, v.56, p.1743-1749, 1990.

HARTUNG, J.S.; CIVEROLO, E.L. Genomic fingerprints of Xanthomonas campestris pv. citri strains from Asia, South America, and Florida. Phytopathology, v.77, p.282-285, 1987.

KUFLU, K.M.; CUPPLES, D.A. Development of a diagnostic DNA probe for xanthomonads causing bacterial spot of peppers and tomatoes Applied and Environmental Microbiology, v.63, p.4462-4470, 1997.

LOPES, S.A.; DAMANN, K.E.; GRELEN, L.B. Comparison of methods for identification of the sugarcane pathogen Xanthomonas albilineans. Summa Phytopathologica, v.24, p.114-119, 1998.

LOUWS, F.J.; FULBRIGHT, D.W.; STEPHENS, C.T.; DEBRUIJN, F.J. Specific genomic fingerprints of phytopathogenic Xanthomonas and Pseudomonas pathovars and strains generated with repetitive sequences and PCR. Applied and Environmental Microbiology, v.60, p.2286-2295, 1994.

MARINGONI, A.C.; LEITE JÚNIOR, R.P.; KOMORI, N. Nova doença bacteriana do pepino (Cucumis sativus L.), causada por Xanthomonas campestris pv. cucurbitae (BRYAN) DYE, no Brasil. Summa Phytopathologica, v.14, p.225-230, 1988.

PAN, Y.B.; GRISHAM, M.P.; BURNER, D.M. A polymerase chain reaction protocol for the detection of Xanthomonas albilineans, the causal agent of sugarcane leaf scald disease. Plant Disease, v.81, p.189-194, 1997.

RESTREPO, S.; VERDIER, V. Geographical differentiation of the population of Xanthomonas axonopodis pv. manihotis in Colombia. Applied and Environmental Microbiology, v.63, p.4427-4434, 1997.

WILLIAMS, J.G.K.; KUBELIK, A.R.; LIVAK, K.J.; RAFALSKI, J.A.; TINGEY, S.V. DNA polymorphisms amplified by arbitrary primers are useful as genetic markers. Nucleic Acid Research, v.18, p.6531-6535, 1990.

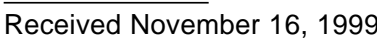

